\title{
The influence of climate change on the intensity and distribution of the rain in four Rio de Janeiro (Brazil) weather stations
}

\author{
A influência das mudanças climáticas na intensidade e distribuição de chuvas em quatro \\ estações meteorológicas do Rio de Janeiro, Brasil
}

\author{
João Octávio Caranzano Moraes ${ }^{1}$ \\ Tammy Caroline Lima Jesús ${ }^{2}$ \\ Fernando Matias ${ }^{3}$ \\ Julio Cesar Wasserman $\left.{ }^{4}{ }^{*}\right)$
}

\section{Abstract}

The purpose of this article was to verify the existence of changes in the distribution and intensity of rainfall in four rainfall stations. The standard deviation and the trend were studied to understand the rain intensity along the series. The Kolmogorov-Smirnov test was applied to check if changes occur in the rain distribution over time. The standard deviation shows high variety in rainfall intensity during the whole 70 years series, but the trend indicates increase in the annual precipitation. The Kolmogorov-Smirnov test does not reject the hypothesis that all distributions studied are not different between them. Therefore, it is concluded that in the studied time series for each station there were no significant changes in the rainfall distribution, although the annual rainfall amount tends to increase.

Keywords: climate change; Kolmogorov-Smirnov test; rainfall intensity, rainfall trend.

\section{Resumo}

O propósito deste artigo foi verificar a existência de mudanças na distribuição e intensidade da precipitação em quatro estações meteorológicas. $\mathrm{O}$ desvio padrão e a tendência foram estudados para compreender a intensidade da chuva ao longo das séries temporais. O teste de Kolmogorov-Smirnov foi aplicado para identificar possíveis mudanças na distribuição da precipitação no tempo. O desvio padrão mostrou elevada

1 Me.; Engenharia de Biossistemas; Universidade Federal Fluminense, UFF, Brasil; Professor titular na Associaçäo Educacional Dom Bosco, AEDB, Brasil; Endereço: Av. Cel. Prof. Antônio Esteves, 1 - Campo de Aviação, Resende - RJ, 27523-000; E-mail: caranzano@hotmail.com

2 Doutoranda; Engenharia da Nanotecnologia; Universidade Federal do Rio de Janeiro, UFRJ, Brasil; Endereço: Av. Pedro Calmon, 550 - Cidade Universitária, Rio de Janeiro - RJ, 21941-901; E-mail: tammy-caroline@hotmail.com

3 Me.; Engenheiro de Biossistemas pela Universidade Federal Fluminense e Especialista em Gestão de Áreas Naturais Protegidas pelo Center for Protected Area Management of Colorado State University and U.S. Forest Service (EUA). Superintendente de Biodiversidade e Floretas; Endereço: Av. Venezuela, 110 / 5ªndar. Saúde, Rio de Janeiro / RJ: CEP:20.081-312; E-mail: fernando.ecobio@gmail.com

4 Dr.; Oceanologia; Université Bordeaux Sciences et Technologies, BORDEAUX, França; Professor Titular da Universidade Federal Fluminense e Coordenador da Rede UFF de Meio Ambiente e Desenvolvimento Sustentável, onde tem trabalhado com pesquisa aplicada a problemas ambientais e particularmente focado na dinâmica de poluentes; Endereço: Universidade Federal Fluminense, Rede UFF de Meio Ambiente e Desenvolvimento Sustentável. Outeiro de São João Batista, Escola de Extensão, 20 andar, Centro, 24020-149 - Niteroi, RJ - Brasil E-mail: geowass@vm.uff.br (*) Autor para correspondências

\begin{tabular}{llllll}
\hline Ambiência & Guarapuava (PR) & v.14n.1 & p. 140-153 & Jan/Abr 2018 & ISSN $1808-0251$
\end{tabular}


variação na intensidade da chuva durante todos os períodos considerados, mas a tendência indica que a precipitação anual tende a aumentar. O teste de KolmogorovSmirnov não pôde rejeitar a hipótese de que todas as distribuições não são diferentes entre si. Desta forma, conclui-se que, para as séries de tempo estudadas em cada estação, não houve mudanças significativas na distribuição da precipitação, mas que a quantidade anual de precipitação tendeu a aumentar.

Palavras-chaves: Mudanças climáticas; Teste de Kolmogorov-Smirnov; Intensidade da chuva, Tendência de pluviosidade

\section{INTRODUCTION}

Since the early 1970's, climate change and its impacts on the environment have been widely studied. The global warming perspective in consequence of the greenhouse effect has been the most common focus, leading the scientific community to make multidisciplinary studies and unifying meteorology, oceanography and biology among other knowledge areas. This interdisciplinary effort has been aiming to understand the global environmental dynamics and the Earth feedbacks.

During the last century, climate models were applied in wrong instances, for example, models developed for the temperate United States were used in South America tropical climates. Furthermore, the created scenarios were analyzed for impacts over the very area where it was developed to and the previsions did not consider potential impacts in other places and its feedback. Examples are the studies made on the Amazon deforestation without considering the impact in other places of the planet. So, it can be stated that one restricted scenario can be incapable to consider a wide range of climate interaction, which can make it difficult the interpretation of impact studies results (MARENGO, 2007).

According to the IPCC (Intergovernmental Panel on Climate Change) report published in 2014 it is evident that many extreme events have been affecting several countries, causing deaths, economic and environmental losses (IPCC, 2014). It is possible to list climatic events in recent dates, such as the cold waves in the Northern North America, affecting Canada and the USA in 2013/2014 or the explosive cyclogenesis at the North East Atlantic Ocean, affecting the UK and the North of Spain. In the same period, in Australia, some games of the Australian Open had to be delayed, because of the extreme heat. In 2005, the hurricanes Katrina, Rita and Wilma hit North America and the tropical cyclone Catarina struck Southern Brazil in March 2004.

Current climatic adverse events can be understood as a significant modification on the climatic patterns registered during decades, deviating from the normal average climate conditions (IPCC, 2001). This deviation could be a simple increase in temperature or a more complex shift in the whole structure of the Earth climate. For example, according to several authors (e.g.: Easterling and Wehner, 2009; Foster and Rahmstorf,2011), instead of the expected increase with the introduction of $\mathrm{CO}_{2}$, global temperature decreased in the beginning of the $20^{\text {th }}$ century. More recently, the climatologists Kosaka and Xie (2013) developed a model which denoted cooling in Tropical Pacific Waters (which means 8,2\% of the Earth surface). Considering the hypothesis that oceans are the main climate regulators in the planet, this would be the cause of a $0,15^{\circ} \mathrm{C}$ decrease in global average temperature, compared with the 1990's (Kosaka and Xie, 2013). 
It is remarkable the complexity of meteorological processes, where several variables are linked in a way that small variations at the initial conditions can promote a wide range of behaviors (LORENZ, 1967). The variables of a climate system are interconnected; thus, an increase in $\mathrm{CO}_{2}$ emissions, for example, could destabilize the system. Another relevant factor associated with the climate system is the possible feedbacks. A feedback is the system response to a stimulus, like changes in the atmosphere, in the oceans, in the soils, or in glaciers. It can be positive, if the response amplifies the effect of the stimulus, or negative, if it is attenuated (CESS et al., 1989). Due to the complex factors mentioned, there is not full understanding about atmospheric phenomena and the relationships among them. Although the complex models developed today are capable to reproduce long-term climate changes, their calibration is difficult because series of historical reliable data are relatively short.

Several authors have already studied long-term trends in precipitation. Doyle et al. (2012) found positive trends in annual rainfall in the La Plata Basin considering four decades of data; in Southern Canada, annual precipitation increased between 5\% to 35\% during the twentieth century (ZHANG et al., 2000); Golicher et al. (2006) analyzed the temporal trends using loess smoothing to study the correlation between precipitation patterns and E1 Niño phenomenon in Mexico; droughts frequency in Americas and Russia has decrease, whereas as the Mediterranean region or Southern Australia show an increase in droughts frequency (SPINONI et al., 2013).

In Brazil, according to Cavalcanti et al. (2009), Southeast region has not witnessed major changes in rainfall regimes over the last 50 years. In contrast, according to Silva et al. (2012) J.G.F., this region showed extreme events, such as an increment on the intensity and frequency of rainfall. De Oliveira et al. (2014) stated that heavy rain events in the Northeastern Brazil modulated by El Niño and La Niña presented negative trends in the number of episodes, but positive trends in the amount of daily rainfall. Although the trends can be outlined by these studies, the variability has yet to be better understood and statistical tools may be useful to give more consistency to the observed figures.

This study was thought to analyze precipitation patterns distribution and variability in four rainfall stations, located in the Paraíba do Sul River Basin, in the State of Rio de Janeiro. Providing a long-term record of the rainfall, the behavior at these stations was analyzed with statistical tools.

\section{METHODOLOGY}

The rainfall data of the studied stations were obtained from the Brazilian Water Agency (Agência Nacional de Águas) website, Hidroweb (http://hidroweb.ana.gov.br). Data treatment was made with MS Excel and with the software Assistat. The selection criteria for the stations were the length of the series and the quality of the data. Several stations were evaluated and discarded, using just the ones with, at least, 5 decades and few gaps (Table 1). Among the data from the selected stations, consisted data were preferred to raw data. The position of the rainfall stations is presented in Figure 1. In order to facilitate interpretations, the map represents the hypsometry of the region as well. 
Figure 1: Hypsometric map of the southern portion of the Rio de Janeiro State, showing the location of the rainfall stations.

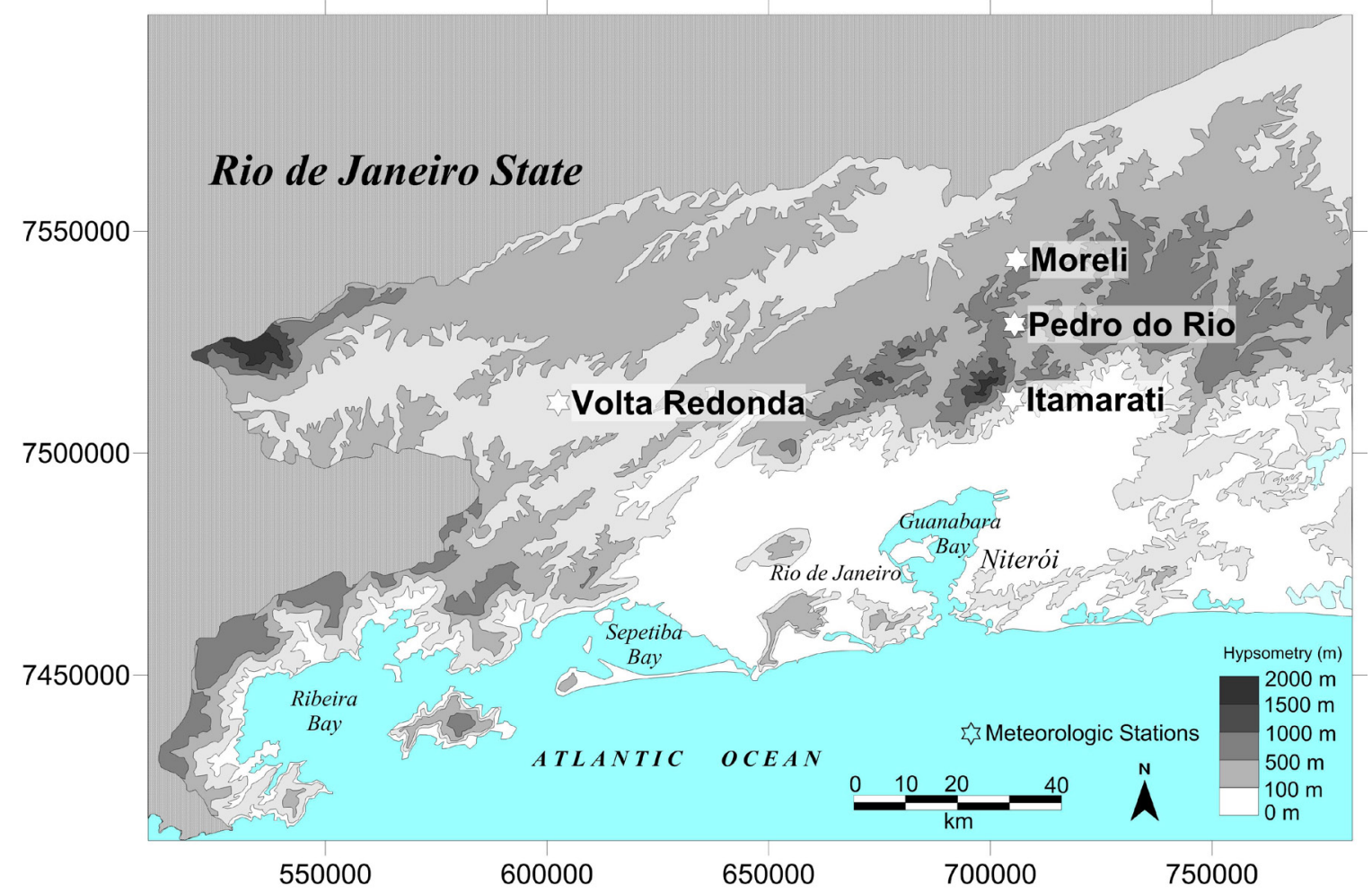

by Wasserman 2014, Source: IBGE

Table 1: Rainfall stations

\begin{tabular}{ccccccc}
\hline Station & 23 K, E & N & Code & Basin & Series & $\begin{array}{c}\text { Period } \\
\text { (years) }\end{array}$ \\
\hline Moreli & 705911 & 7543590 & 2243016 & 58 & $01 / 1955-12 / 2012$ & 58 \\
Pedro do Rio & 705420 & 7529010 & 2243012 & 58 & $12 / 1938-01 / 2013$ & 74 \\
Itamarati & 704990 & 7512103 & 2243010 & 58 & $01 / 1938-08 / 2005$ & 68 \\
$\begin{array}{c}\text { Volta } \\
\text { Redonda }\end{array}$ & 602477 & 7511365 & 2244041 & 58 & $01 / 1944-01 / 2013$ & 69 \\
\hline
\end{tabular}

\section{Statistical analysis}

A graph was created using Excel to analyze the trend and the total annual precipitations behavior compared to the averages. The results represented the total rainfall of each year of the series, the annual rainfall average of the series and the total annual precipitations trend. The objective was to verify if there is a continuous variability during the whole series or if the variability was more remarkable during a specific period, or if variations are random. The trend indicates whether the average annual precipitation increases or decreases during the series. 
The frequency was calculated and presented in a histogram with ten rainfall classes. Average monthly rainfall and standard deviation were calculated, and the number of individuals outside the range $\mu \pm 2 \sigma$ was analyzed. Different tests were carried out using the software ASSISTAT to verify if the distribution of the rainfall was Gaussian or not. The tests of Normality used in this study were Kolmogorov-Smirnov, Cramér-von Mises, Anderson-Darling, Kuiper, Watson, Lilliefors and Shapiro-Wilk.

\section{Kolmogorov-Smirnov test}

The K-S test compares the distribution of two samplings. The null hypothesis is that both samples have the same distribution, but it is also used to compare one sample with a reference distribution previously known. This test was chosen for being one of the most popular in climatological and meteorological literature (VLCĚK and HUTH, 2009).

The calculation can be carried out using Matlab, with the code " $b=k s t e s t 2\left(x_{1}, x_{2}\right)$ ", where $x_{1}$ and $x_{2}$ are the data of the series to be compared. For instance, the average monthly rainfall of decade 1 and decade 2 . If the result is 0 , the test cannot reject the null hypothesis, i.e., the distributions cannot be considered different. However, in this work, the Kolmogorov-Smirnov test was calculated using Excel, inserting the distribution data in two columns, in two other columns the accumulated frequencies, and in one more column the differences between frequencies. If any difference value is greater than the critical D (which depends on the number of samples and the level of significance), it rejects the null hypothesis. Otherwise the test cannot reject the null hypothesis of two distributions that are not different (both distributions belong to the same sample). For instance, for $\mathrm{n}=12$ and $\alpha_{0}=5 \%$, when comparing average monthly rainfall distributions of two decades, the critical $\mathrm{D}$ is 0.3754 .

This study compared the following distributions for each rainfall station (level of significance $\alpha 0=5 \%)$ :

- Average monthly rainfall distribution of the first $75 \%$ of the years compared with the average monthly rainfall distribution of the last $25 \%$ years of the series.

- Average monthly rainfall distribution of the first $75 \%$ of the years compared with the total monthly rainfall distribution of each year of the last $25 \%$ years of the series.

- Average monthly rainfall distribution of each decade compared one by one.

- Hypothesis of uniform distribution of the highest daily rainfalls (corresponding to 1\% of the total number of entries) clustered in decades.

For instance, if the series had 10,000 entries of daily rainfall, the highest values 100 (1\%) were analyzed after being grouped by decades. To make this calculation, the daily rainfall data were organized in a matrix where the days of the month were in the columns and the months and years were in the rows, i.e., each month, from the first to the last day, was in a single row. Alongside, another matrix was built with the same number of rows and columns, and with the same structure (months in the rows and days in the columns). Each position in this later matrix would be 1 if the rainfall that day in the first matrix was between $1 \%$ of highest values, or 0 otherwise. Then, the number of 1 was counted for each decade, and the total was normalized dividing by the number of entries (days) in the series each decade. The Kolmogorov-Smirnov Test was applied to the normalized distribution to find out if the $1 \%$ of highest values of rainfall behaved as a uniform distribution throughout the years. 


\section{RESULTS AND DISCUSSION}

\section{Statistical analysis}

Figures 2-5 show the total annual precipitation at Morelli, Pedro do Rio, Itamarati and Volta Redonda rainfall stations, respectively. The trend equations of the data are shown in Table 2. It can be observed in all the stations that the total annual rainfall alternates above and below the average (red line). However, the trend of total annual precipitation (slope, green line) is positive throughout the period in all stations.

Figure 2: Annual rainfall, average and trend in the station Morelli. Where the trend is green, while the red line represents the average.

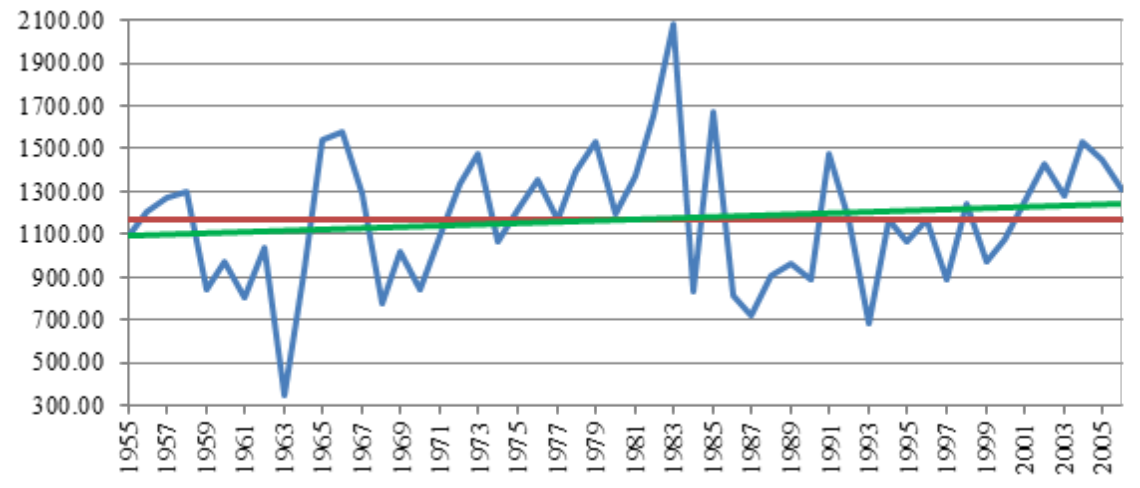

Figure 3: Annual rainfall, average and trend in the station Pedro do Rio. Where the trend is green, while the red line represents the average.

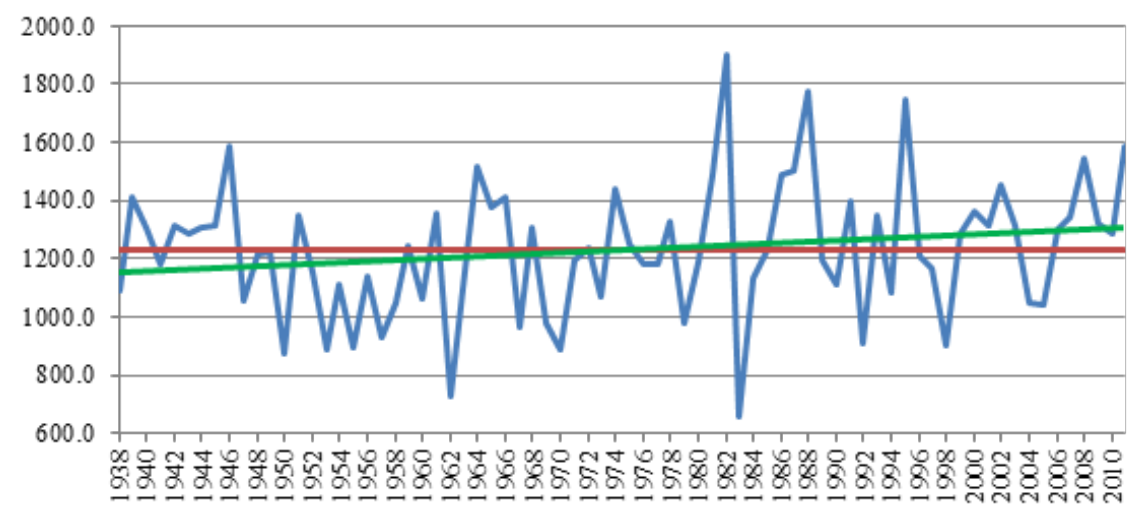


Figure 4: Annual rainfall, average and trend in the station Itamarati. Where the trend is green, while the red line represents the average.

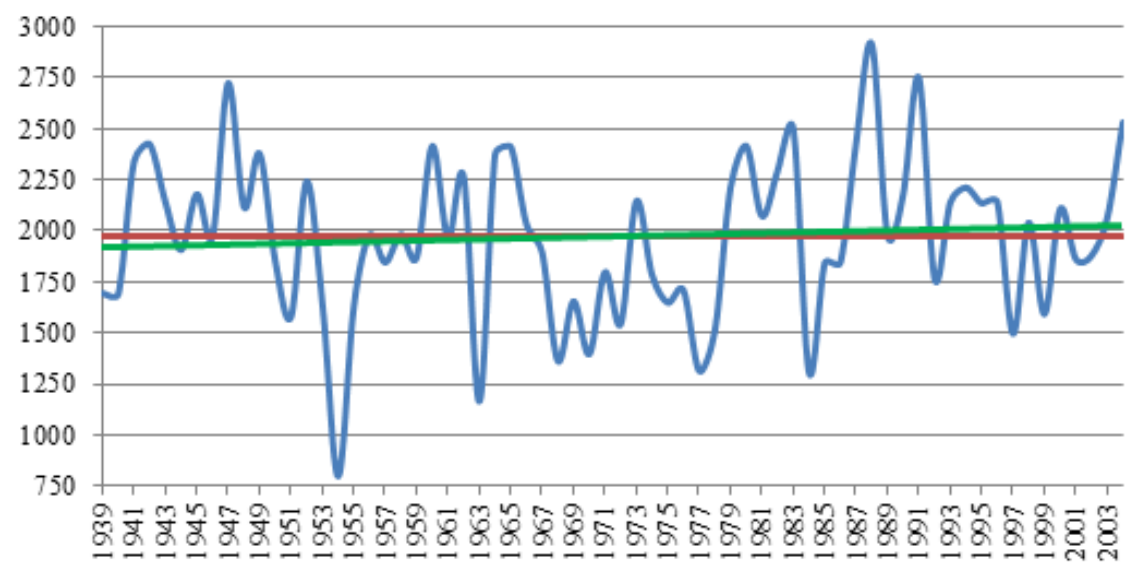

Figure 5: Annual rainfall, average and trend in the station Volta Redonda. Where the trend is green, while the red line represents the average.

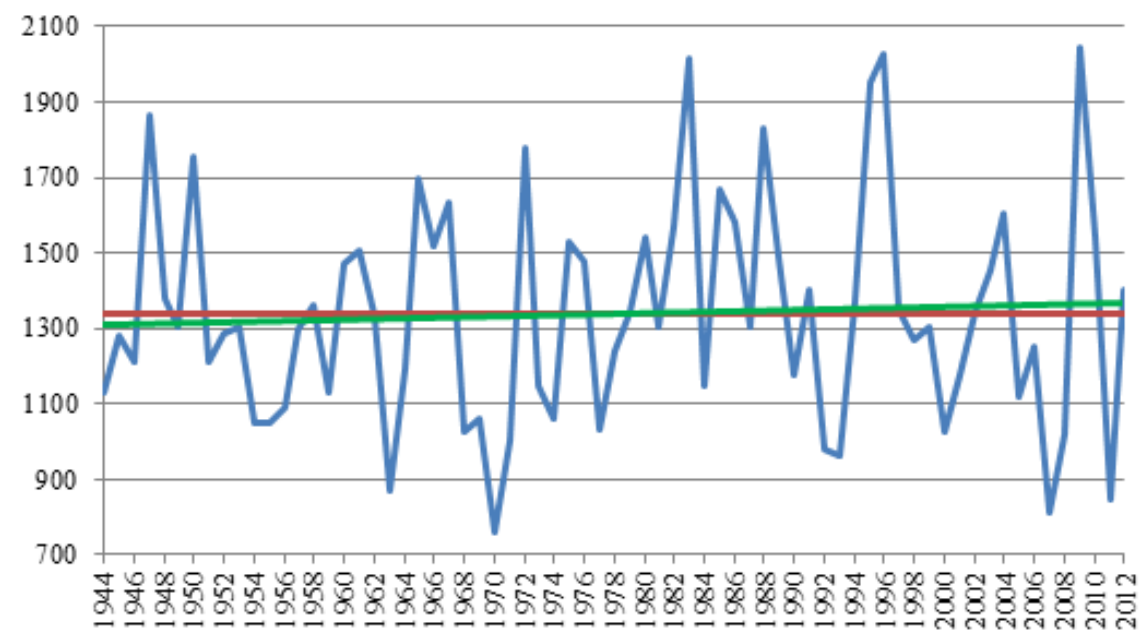

Table 2 shows that all stations have a positive slope, i.e., the trends of the annual rainfall in all stations grow. Morelli station had the greatest growth trend; this is possibly because the data series began in the decade of 1950s, which was drier than the 1940s, and this can have increased the slope. The slopes for the other stations were calculated considering just the period from 1955 and both Pedro do Rio and Itamarati had higher values than Morelli. The lowest slope occurred at Volta Redonda station, which showed a slightly different behavior compared to the others. In Volta Redonda, the 1950's were not as dry, but it is possible to visualize in the graphs that the alternation of years with values below and above the average occurs more often than in the other stations, although the standard deviations of Morelli $(239,9)$ and Itamarati $(311,2)$ were higher than in Volta Redonda $(233,2)$. Furthermore, as it can be seen in Figure 1, this station is located some $100 \mathrm{~km}$ away from the other station, which are close to each other (some $30 \mathrm{~km}$ ). 
Table 2: Annual rainfall trend equations

\begin{tabular}{cccc}
\hline Station & Equation* & Slope & Trend \\
\hline Moreli & $\mathrm{y}=3,0052 \mathrm{x}$ & $>0$ & Annual rainfall increases \\
Pedro do Rio & $\mathrm{y}=2,1367 \mathrm{x}$ & $>0$ & Annual rainfall increases \\
Itamarati & $\mathrm{y}=1,6168 \mathrm{x}$ & $>0$ & Annual rainfall increases \\
Volta Redonda & $\mathrm{y}=0,8575 \mathrm{x}$ & $>0$ & Annual rainfall increases \\
\hline
\end{tabular}

*Wherex is the number of theyear in the series, beginning from 0 . Therefore, the value of the intersection point corresponds to the trend calculated for the first year of the series.

Figure 6 shows histograms of precipitation frequencies, classified in ten intervals for the studied stations. The graphs show that the average monthly rainfall at Volta Redonda station is more spread than at the others, corroborating the analysis of trend results for this station. The skewness (Table 3) indicates that Volta Redonda station has a smaller variation in rainwater throughout the years, what should be attributed to the fact that this station is located farther west from the others and in a flatter terrain (Figure 1). For the other stations, it is also possible that the effect of the relief influences the rainfall. Particularly Itamarati, located in the southern face of the Serra do Mar (Mar Ridge, Figure 1), receives an important orographic influence, justifying the higher rainfall values.

Table 3: Skewness of the frequencies of the four rainfall stations for the studied period.

\begin{tabular}{ccccc}
\hline & Morelli & Pedro do Rio & Itamarati & Volta Redonda \\
\hline Skewness & 0,153145 & 0,204485 & -0.2312469 & 0,499981 \\
\hline
\end{tabular}

Table 4 presents the results of the Normality tests applied to the data series. For all rainfall stations, there were both more months that were considered non-Gaussian and more tests that considered the monthly distribution as non-Gaussian. These tests reinforce the results presented at Table 3 and Figure 6, where none of the stations clearly behaves as Gaussian; furthermore, Volta Redonda rainfall behavior is clearly more non-Gaussian than at the other stations, and Itamaraty rainfall is closer similar to the Gaussian distribution, although all stations can be considered to have non-Gaussian distributions.

Figure 6: Rainfall frequencies in the four stations (according to ten classes for each station).

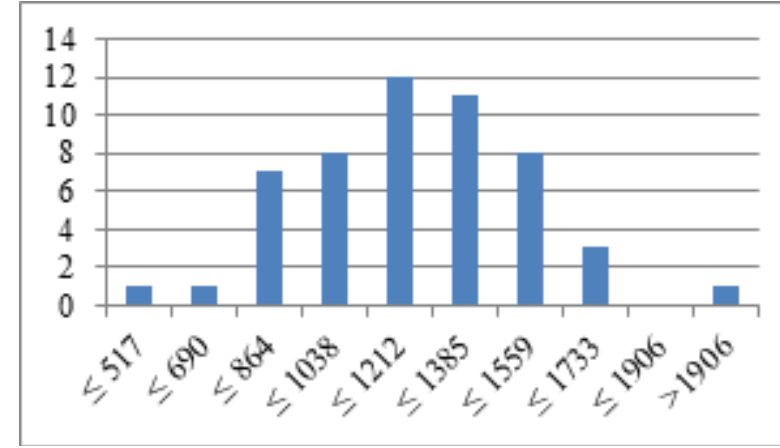

a) Morelli

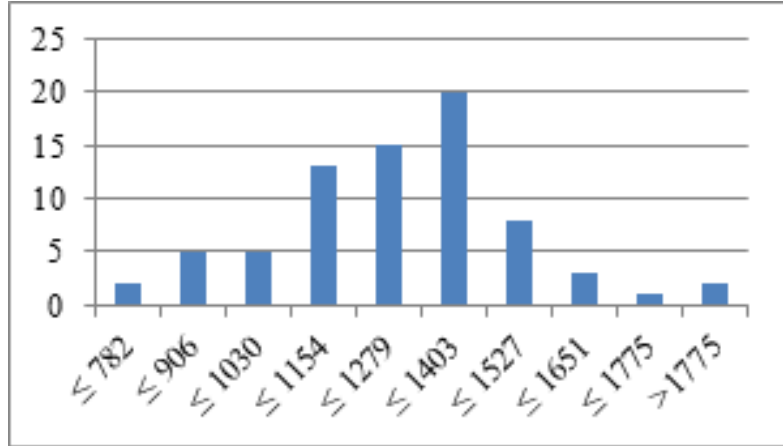

b) Pedro do Rio 


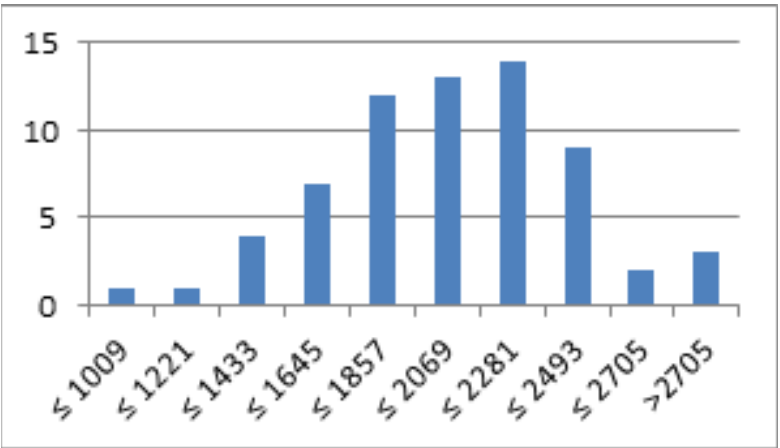

c) Itamarati

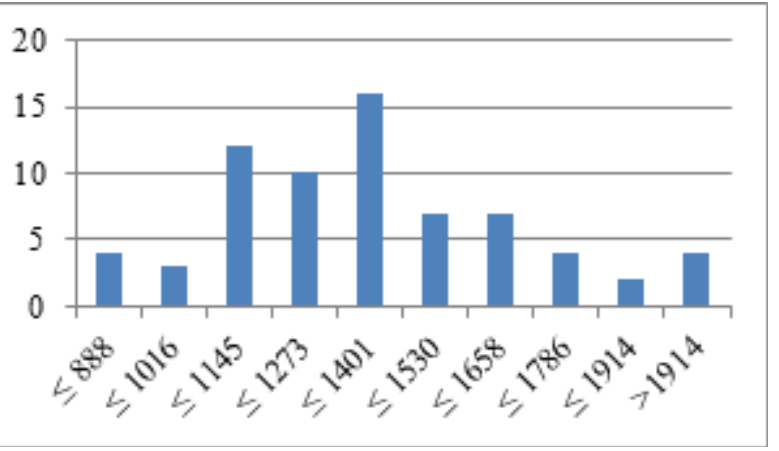

d) Volta Redonda

Table 4: Gaussian versus non-Gaussian results, where the columns corresponding to "Month results" show the number of months considered either Gaussian or non-Gaussian by the tests, and the columns corresponding to "Test results" represent the tests in which the majority of the months were considered either Gaussian or non-Gaussian, or the total number of Gaussian and non-Gaussian months for one test was the same (six months of each, therefore the results are "even").

\begin{tabular}{c|cc|c|ccc}
\hline & \multicolumn{2}{|c|}{ Month results } & \multicolumn{3}{c}{ Test results } \\
& Gaussian & Non-Gaussian & Gaussian & Non-Gaussian & Even \\
\hline Morelli & 37 & 47 & 0 & 4 & 3 \\
Pedro do Rio & 31 & 53 & 0 & 5 & 2 \\
Itamarati & 40 & 44 & 2 & 3 & 2 \\
Volta Redonda & 25 & 59 & 0 & 7 & 0 \\
\hline
\end{tabular}

Considering Figures $2-5$ it can be stated that, although the observed trend is consistent in all stations, it is quite small compared with the variation and should be attributed to the drought of the decade 1950. In order to see the influence of this drought on the overall trend, we made a simple experiment, repeating the data of this period as if they were the data for the next ten years. Results of the estimated calculations are shown in Table 5, where it can be observed that the trends declined severely, attaining negative values in Itamarati and Volta Redonda.

Table 5: Simulated overall trends, as given by the of the rainfall, by repeating the drought period of the 1950's in the next 10 years

\begin{tabular}{cccc}
\hline Station & Equation* & Slope & Trend \\
\hline Moreli & $\mathrm{y}=2.043486 \mathrm{x} *$ & $>0$ & Annual rainfall increases. \\
Pedro do Rio & $\mathrm{y}=0.204304 \mathrm{x}$ & $>0$ & Annual rainfall increases \\
Itamarati & $\mathrm{y}=-0,9707 \mathrm{x}$ & $<0$ & Annual rainfall decreases \\
Volta Redonda & $\mathrm{y}=-0.19694 \mathrm{x}$ & $<0$ & Annual rainfall decreases \\
\hline
\end{tabular}

*Where $x$ is the number of the year in the series, beginning from 0. Therefore, the value of the intersection point corresponds to the trend calculated for the first year of the series.

**This station was installed in 1955, thus the whole decade was not repeated. 


\section{Kolmogorov-Smirnov Test}

According to the Kolmogorov-Smirnov test, when it was applied to compare the average monthly rainfall distribution of the first $75 \%$ years and the average monthly rainfall distribution of the last $25 \%$ years of the series, in 0 years ( 0 times) the null hypothesis was rejected. This means that there are no significant differences between the monthly average rainfall distributions of the periods. Just as the other statistics presented in this article, the absence of difference does not mean that the rainfall is not changing, but variations are not strong enough for the change to be detected. A larger sample of rainfall stations worldwide spread should return more precise information.

As the latter results did not reject the null hypothesis, another experiment using the same data was carried out. Instead of using the average value of the last $25 \%$ of the years, a comparison was made for each year of those last $25 \%$. In the comparison of the average monthly rainfall distribution of the first $75 \%$ years and the total monthly rainfall distribution of each year of the last $25 \%$ years of the series, the null hypothesis could not be rejected for any year for all the stations.

In the comparison of decades one by one for each rainfall station, the null hypothesis was not rejected in any case. Even when comparing the years 1940's with 2000 in all four stations, no changes were statistically detected. In this treatment, it can be observed once again that the statistics do not prove the significant variations in rainfall distribution (seasonality). However, it is observed in Figures 2-5 and in the whole statistical treatments throughout this work that the large variations in rainfall of the four stations do not allow any statistical recognition of the rainfall seasonality.

In the comparison of the distributions of the greatest daily rainfalls corresponding to $1 \%$ of the days of the series by decades to the uniform distribution the experiment did not present any significant variation, therefore they cannot be considered different to the uniform distribution. It can be speculated the Kolmogorov-Smirnov test is not sensitive enough to indicate any general trend, but based on the results of these four meteorological stations it is proved that the variation is so broad that this trend (if it really exists) is not possibly detected.

It is interesting to note that scientists have been using statistics to corroborate observations since Auguste Conte invented the positivism. However, in our study we show that the available statistics are not strong enough to prove the slight growing trends observed in the widely variable rainfall of the last 70 years.

\section{CONCLUSIONS}

According to the standard deviation results, there is a large variability in rainfall patterns not only seasonal, but among the years as well. The study of the averages indicates that there are years with data above and below the monthly average rainfall of each month for each station. In all the stations, there are more data outside the interval $\mu \pm 2 \sigma$ than it would be expected if the distribution of monthly precipitation for each month was Gaussian. Besides, considering the results of the Normality tests, all the rainfall stations present non-Gaussian behavior more often than Gaussian. Furthermore, according to the results, the probability of extreme rainfall is greater than if the distribution was normal and this happens during the entire studied period, not only more recently. 
The amount of annual rainfall, although has a wide variability, tends to increase. The equations of the trend of the four stations had positive slopes, i.e., annual rainfall tends to increase. However, the trend is not very pronounced, and the number of studied stations (four) is not very high to allow an extrapolation for world climate change. The influence of the drought of the 1950's was proved to be significant. Therefore, this conclusion must be taken with caution, as it may be happening only at the local level, the studied sub-basin.

Kolmogorov-Smirnov tests indicate that there are no significant variations in the distribution of precipitation studied. This does not mean that there are no differences in the distributions, but this difference does not reach the $5 \%$ level of significance. There is still much to learn about the balance of the planet, and the fact that the test does not indicate differences between distributions, does not mean that there is a climate imbalance. In nature there are many unstable equilibria and chaotic phenomena, for which any change, no matter how small, express into a wide range of results and the present statistics is not able to unravel.

The amount of data, between 5 and 7 decades is higher than the climatological normal (30 years, according to the World Meteorological Organization). However, climate change can be measured by centuries, millennia or even for larger time intervals. The influence of extraterrestrial phenomena such as solar storms, which are cyclic, and the movement of Earth's rotation, translation, precession, eccentricity and inclination of the axis, have different effects on climate. The man, in turn, may also be influencing this balance through the emission of greenhouse gases. This leads to understand the results of this study with caution: first, the tests indicate that there are no variations in the distributions, but the data series are decades, and anthropogenic effects on the atmosphere can take much longer to produce radical irreversible effects on the climate.

Further studies on the evaluation of climate changes using statistics, but on a global basis are necessary. If a large number of worldwide representative stations are considered, it is possible that variations can be homogenized, making tests more sensitive to smaller changes and a significant trend can effectively be observed.

\section{ACKNOWLEDGEMENTS}

Authors thank CAPES for the economic support. JCW is grateful to CNPq that granted a research scholarship (process \#306714/2013-2).

\section{REFERENCES}

CAVAlCANTI, I. F. D. A. et al., Eds. Tempo e Clima no Brasil. São Paulo: Oficina de Textos, p.464, 1 ed. 2009.

CESS, R. D. et al. Interpretation of cloud-climate feedback as produced by 14 atmospheric general-circulation models. Science, v. 245, n. 4917, p. 513-516, Aug 1989. ISSN 00368075. Disponível em: < <Go to ISI >://WOS:A1989AJ11900036 >.

DE OLIVEIRA, P.T.; SILVA, C. M. S. E.; LIMA, K. C. Linear trend of occurrence and 
intensity of heavy rainfall events on Northeast Brazil. Atmospheric Science Letters, v. 15, n. 3,p.172-177, 2014. Disponível em: $<$ http://www.scopus.com/inward/record.url?eid=2s2.0-84904552621\&partnerID $=40 \& \mathrm{md} 5=22 \mathrm{~b} 67 \mathrm{ce} 896 \mathrm{~d} 048 \mathrm{bd} 88 \mathrm{f} 3 \mathrm{c} 7 \mathrm{c} 516313273>$.

DOYLE, M. E.; SAURRAL, R. I.; BARROS, V. R. Trends in the distributions of aggregated monthly precipitation over the La Plata Basin. International Journal of Climatology, v. 32, n. 14, p. 2149-2162, Nov 2012. ISSN 0899-8418. Disponível em: < $<$ Go to ISI $>$ ://WOS:000310985800005 >.

EASTERLING,D. R.;WEHNER,M.F.Is the climate warming or cooling? Geophysical Research Letters, v. 36, p. 3, Apr 2009.ISSN 0094-8276. Disponível em: < <Go to ISI >:// WOS:000265534200004 >.

FOSTER, G.; RAHMSTORF, S. Global temperature evolution 1979-2010. Environmental Research Letters, v. 6, n. 4, p. 8, Oct-Dec 2011. ISSN 1748-9326. Disponível em: < <Go to ISI >//WOS:000298674700027 >.

GOLICHER,J.D.; RAMIREZ-MARCIAL, N.;TACHER, S.I.L. Correlations between precipitation patterns in Southern Mexico and the El Nino sea surface temperature index. Interciencia, v. 31, n. 2, p. 80-86, Feb 2006. ISSN 0378-1844. Disponível em: < < Go to ISI $>$ ://WOS:000235903000002 >.

IPCC. Climate Change 2001: Synthesis Report. A Contribution of Working Groups I, II, and III to the Third Assessment Report of the Intergovernmental Panel on Climate Change. Cambridge University Press. Cambridge, United Kingdom; New York, NY, USA, p.398. 2001

. Summary for Policymakers,. In: EDENHOFER, O.;PICHS-MADRUGA, R., et al (Ed.). Climate Change 2014, Mitigation of Climate Change. Contribution of Working Group III to the Fifth Assessment Report of the Intergovernmental Panel on Climate Change Cambridge, UK; New York, USA: Cambridge University Press, 2014. p.33.

KOSAKA, Y.; XIE, S. P. Recent global-warming hiatus tied to equatorial Pacific surface cooling. Nature, v. 501, n. 7467, p. 403-+, Sep 2013. ISSN 0028-0836. Disponível em: < $<$ Go to ISI $>$ ://WOS:000324545700042 >.

LORENZ, E. N. The Nature and Theory of the General Circulation of the Atmosphere. World Meteorologic Organization Bulletin, v. April, p. 74-78, 1967.

MARENGO,J.A. Mudanças Climáticas Globais e seus Efeitos sobre a Biodiversidade. Caracterização do Clima Atual e Definição das Alterações Climáticas para o Território Brasileiro ao Longo do Século XXI. Ministério do Meio Ambiente. Brasília, DF, p.82. 2007. 
SILVA,J. G. F. et al. Análise da frequência de chuvas no município de Vila Velha. Revista FACEVV (Faculdade Cenecista de Vila Velha), v. 9, n. 064-077, 2012.

SPINONI, J. et al. World drought frequency, duration, and severity for 1951-2010. International Journal of Climatology, v. 34, n. 8, p. 2792-2804, 2013. Disponível em: $<$ http://www.scopus.com/inward/record.url?eid=2-s2.0-84902677326\&partnerID=40

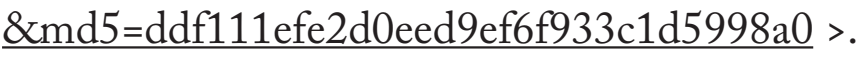

VLCEK, O.; HUTH, R. Is daily precipitation Gamma-distributed? Adverse effects of an incorrect use of the Kolmogorov-Smirnov test. Atmospheric Research, v. 93, n. 4, p. 759-766, Aug 2009. ISSN 0169-8095. Disponível em: < <Go to ISI >:// WOS:000268352000009 >.

ZHANG, $X$. et al. Temperature and precipitation trends in Canada during the 20th century. Atmosphere-Ocean, v. 38, n. 3, p. 395-429, 2000/09/01 2000. ISSN 0705-5900. Disponível em: < http://dx.doi.org/10.1080/07055900.2000.9649654 >. 